DEMOGRAPHIC RESEARCH

VOLUME 41, ARTICLE 16, PAGES 461-476 PUBLISHED 1 AUGUST 2019

http://www.demographic-research.org/Volumes/Vol41/16/

DOI: 10.4054/DemRes.2019.41.16

Descriptive Finding

\title{
The role of education and educational- occupational mismatches in decisions regarding commuting and interregional migration from eastern to western Germany
}

\section{Silvia Maja Melzer}

\section{Thomas Hinz}

This publication is part of the Special Collection on "Spatial Mobility, Family Dynamics and Gender Relations," organized by Guest Editors Sergi Vidal and Johannes Huinink.

(C) 2019 Silvia Maja Melzer \& Thomas Hinz.

This open-access work is published under the terms of the Creative Commons Attribution 3.0 Germany (CC BY 3.0 DE), which permits use, reproduction, and distribution in any medium, provided the original author(s) and source are given credit.

See https://creativecommons.org/licenses/by/3.0/de/legalcode. 


\section{Contents}

1 Introduction $\quad 462$

2 Data and methods 463

2.1 Data 463

2.2 Methods 466

$3 \quad$ Results 466

3.1 Who chooses to commute and who chooses to migrate from eastern 466

3.2 Commuting as a stepping-stone, or as an alternative? 468

$4 \quad$ Discussion and conclusion $\quad 470$

$\begin{array}{ll}\text { References } & 473\end{array}$ 


\title{
The role of education and educational-occupational mismatches in decisions regarding commuting and interregional migration from eastern to western Germany
}

\author{
Silvia Maja Melzer ${ }^{1}$ \\ Thomas Hinz ${ }^{2}$
}

\begin{abstract}
OBJECTIVE

This paper investigates commuting and interregional migration from eastern to western Germany, and asks, first: Who chooses to migrate and who chooses to commute? Second: Does commuting serve as a stepping-stone or as a long-term alternative to migration? And third: What role does education and educational-occupational mismatch play in those choices?
\end{abstract}

\section{METHODS}

We use the Socio-Economic Panel data from 1992 to 2013 and multilevel multinomial logit models with random effects, as well as cross-classified multilevel logit with random effects.

\section{RESULTS}

People with higher education are more likely to migrate than to remain immobile or to commute, while people who have spent less time in education are more likely to commute than to remain immobile or to migrate. Educational-occupational mismatches reduce the likelihood of migration for both men and women, but they reduce the likelihood of commuting only for men. For women, educational-occupational mismatches increase the likelihood of commuting. Moreover, commuting serves as a stepping-stone to migration, rather than as a long-term alternative to it, especially for the highly educated.

\section{CONTRIBUTION}

We investigate the relationship between migration and commuting more directly than has been the case in previous research. Moreover, we advance previous research by showing how educational-occupational mismatch influences decisions as to whether to

\footnotetext{
${ }^{1}$ Universität Bielefeld, Germany. Email: Silvia.Melzer@uni-bielefeld.de.

${ }^{2}$ Universität Konstanz, Germany. Email: Thomas.Hinz@uni-konstanz.de.
} 
commute or to migrate. Our analysis shows how education, educational-occupational mismatch, and gender are interrelated and intertwined with each other, and how genderspecific mobility patterns follow from these interrelations.

\section{Introduction}

This paper examines the role of education and educational-occupational mismatch in men's and women's job-related mobility from eastern to western Germany, including both interregional migration and commuting.

Even though previous research on interregional migration and commuting has underlined the necessity of investigating both forms of mobility simultaneously (e.g., Brown et al. 2015; Lundholm 2010: 462), to date interregional migration (e.g., Huinink, Vidal, and Kley 2014; Melzer 2013; Nivalainen 2010) and commuting (e.g., Huber 2012, 2014; Sandow and Westin 2010) have usually been investigated separately (Eliasson, Lindgren, and Westerlund 2003: 828; Nivalainen 2010: 146; some exceptions are Brown et al. 2015; Green, Hogarth, and Shackleton 1999; Huber 2014; Hunt 2006; Kalter 1994; Pfaff 2012; Romaní, Suriñach, and Artiís 2003). Ignoring the fact that both forms of mobility are interrelated and can either substitute for (Green, Hogarth, and Shackleton 1999; Nivalainen 2010) or complement each other (Lundholm 2010; Sandow and Westin 2010), leads to incomplete investigations (Romaní, Suriñach, and Artiís 2003) and, in the worst case, to biased results. For instance, analyzing migration without commuting is problematic, as either the population at risk of interregional migration is incomplete because commuters are excluded from the sample, or the categories of analysis are blurred because commuters and people who remain immobile are combined in one group (Melzer 2016). Thus, there is still a need for a thorough, solid, and adequately combined research strategy focusing on both forms of mobility.

Our primary contribution to the research literature on job-related spatial mobility is to investigate migration and commuting simultaneously. First, we ask who chooses to migrate and who chooses to commute. Second, we explore the interrelation between these forms of mobility, investigating whether commuting serves as a short-term solution and thus as a stepping-stone to migration, or whether it is a long-term solution and therefore a substitute for migration. As the long-term costs of commuting are higher than the long-term costs of migration, we expect that people use commuting as a stepping-stone to migration, rather than as an alternative to it (cf. Melzer 2016). Following previous research on migration from eastern to western Germany, we expect women to be more likely to migrate but less likely to commute (cf. Hunt 2006). 
Existing research emphasizes the importance of education in mobility choices, both as a theoretical consideration (Borjas 1987; Sjaastad 1962) and as an empirical finding, indicating that the highly educated are more likely to migrate (e.g., Borjas 1987; Melzer 2013, 2016; Nivalainen 2010). In line with the few studies that investigate the impact of education on commuting and migration simultaneously, we expect that higher education fosters both migration and commuting, compared to remaining stationary (e.g., Eliasson, Lindgren, and Westerlund 2003; Huber 2014; Hunt 2006; Lundholm 2010; Melzer 2016; Nivalainen 2010; Romaní, Suriñach, and Artí́s 2003). However, we expect commuters to be generally less-educated than migrants (e.g., Huber 2014; Hunt 2006; Melzer 2016; Sandow and Westin 2010).

We advance the existing research by asking what role educational-occupational mismatches play in migration and commuting from eastern to western Germany. Both forms of mobility are overwhelmingly directed from the economically weaker eastern Germany to the economically stronger western Germany (Haas and Hamann 2008; Haas 2012; Melzer 2016; Statistisches Bundesamt 2010: 13). Mobility and educationaloccupational mismatches are interrelated and have been treated in the literature on educational-occupational mismatch as competing choices (Büchel and Battu 2003). Regional labor markets, especially when they are economically weak as in eastern Germany, provide limited job opportunities and increase the chances of bad educational-occupational matches, while commuting and migration can help to avoid such unfavorable job matches (Büchel and Battu 2003). Facing an unsatisfactory job offer, a person chooses between: (1) accepting the job offer and working in a bad job match; (2) remaining unemployed; and (3) applying for jobs outside the region and eventually becoming mobile. We assume that there is a path dependency in mobility choices and that people who are currently working in inadequately matched jobs have already faced the decision between mobility and a bad job match and decided against mobility, and will decide the same in the future. However, we expect the negative effect of inadequately matched jobs to be weaker on commuting than migration, as commuting permits remaining in one's region of origin.

\section{Data and methods}

\subsection{Data}

We use the Socio-Economic Panel (SOEP) from 1992 to 2013, a representative longitudinal survey of German private households that has been running in eastern Germany since 1990 (Wagner, Frick, and Schupp 2007). The sample consists of the 
Melzer \& Hinz: The role of education and educational-occupational mismatches

working-age population between 16 and 63 years that spent at least one year in eastern Germany.

For the analysis of mobility choices (presented in Table 2), the dependent variable, mobility form, distinguishes between people who are currently immobile ( $\sim$ stayer), people who currently commute ( commuters) on a daily or weekly basis from eastern to western Germany, and those who migrated ( migrants) during the previous year. Migration is identified as a change of address from eastern to western Germany between two years. As we are interested in the events that lead to migration and not its consequences, migration represents a terminal event and periods following migration are censored. Such censoring does not apply to commuting episodes, as persons who are currently commuting are still potential migrants. To increase the comparability between migrants, commuters, and stayers, this sample includes only the working population, as commuters are by definition employed. It is composed of 7,390 people (and 48,788 yearly observations), among whom 1,282 commute (4,110 observations) and 398 (405 observations) migrate.

To investigate how commuting and migration are interrelated, we use the migration dummy as a dependent variable and commuting as an independent dummy variable indicating that a person is currently commuting. To capture all the motives that cause people to migrate, in the second analysis we also include persons who are currently unemployed. Being unemployed might be an alternative to regional mobility, but unemployed will also have the greatest incentive to migrate, as migration could allow them to return to work. This extends the data to 73,631 observations for a total of 9,477 persons (see Table 1).

The independent variables of main interest to us are education, measured in years, and educational-occupational mismatch, measured as a dummy variable. To facilitate our interpretation, education is centered at nine years, which corresponds to a lower secondary school diploma.

Following the operationalization by Büchel and Battu (2003: 5), educationaloccupational mismatch is measured by contrasting actual educational level with a subjective evaluation of the skills necessary to perform a job. If the discordance between the subjective evaluation of the necessary skills to perform a job and the actual formal educational level was 'substantially' high, and a respondent specified that they were working in a job where they did not need their qualification, they were classified as inadequately matched. In a second step, a variable on occupational position was used to validate this construct.

Table 1 displays the characteristics of migrants, commuters, and stayers. To capture the determinants of interregional mobility, the characteristics of migrants are displayed in the last year before relocation and the characteristics of commuters in the last year before commuting starts. Commuters have only slightly higher levels of 
education than stayers (additional 0.3 years), while migrants spend 0.8 years longer in the educational system and commuters who migrate spend 0.5 years longer (see Table 1). $12.1 \%$ of stayers and $14.6 \%$ of stayers who start commuting are in a bad job match, compared with only $7.2 \%$ of migrants. Among persons actively engaged in commuting, $15.7 \%$ are in a bad job match, but only $10.1 \%$ of commuters who are going to migrate soon are in bad job matches.

Table 1: Descriptive results: characteristics of people who remain immobile (stayers), who commute (Com.), and those who migrate (Mig.) for 1992-2013

\begin{tabular}{|c|c|c|c|c|c|c|c|c|}
\hline & $\begin{array}{l}(1) \\
\min \end{array}$ & $\begin{array}{l}\text { All } \\
(2) \\
\max \end{array}$ & $\begin{array}{l}(3) \\
\text { mean }\end{array}$ & $\begin{array}{c}\text { Stayers } \\
(4) \\
\text { mean }\end{array}$ & $\begin{array}{c}\text { Stayers } \\
\text { who start } \\
\text { Com.* } \\
(5) \\
\text { mean }\end{array}$ & $\begin{array}{l}\text { Com. } \\
(6) \\
\text { mean }\end{array}$ & $\begin{array}{c}\text { Com. who } \\
\text { migrate* } \\
(7) \\
\text { mean }\end{array}$ & $\begin{array}{c}\text { Stayers } \\
\text { who } \\
\text { migrate* }^{*} \\
(8) \\
\text { mean }\end{array}$ \\
\hline \multicolumn{9}{|l|}{ Individual characteristics } \\
\hline Female (\%) & 0 & 1 & 51.2 & 52.1 & 37.5 & 37.2 & 56.0 & 57.8 \\
\hline Age & 16.0 & 63.0 & 41.5 & 41.8 & 37.3 & 38.0 & 31.1 & 31.6 \\
\hline Years in education & 7.0 & 18.0 & 12.4 & 12.4 & 12.5 & 12.7 & 13.2 & 12.9 \\
\hline $\begin{array}{l}\text { Occupational-educational } \\
\text { mismatch }(\%)\end{array}$ & 0 & 1 & 12.3 & 12.1 & 14.6 & 15.7 & 10.1 & 7.2 \\
\hline Full-time employed (\%) & 0 & 3 & & & & & & \\
\hline Part-time employed (\%) & & & 9.0 & 9.1 & 9.5 & 7.8 & 7.7 & 5.5 \\
\hline In apprenticeship (\%) & & & 4.2 & 3.9 & 10.1 & 7.4 & 13.7 & 8.5 \\
\hline Unemployed (\%) & & & 32.4 & 34.1 & 9.9 & 3.7 & 7.7 & 37.7 \\
\hline Gross income $(€)$ & 0.0 & 35,000 & 1,150 & 1,101 & 1,591 & 1,953 & 1,744 & 1,075 \\
\hline Log (gross income +1) & 0.0 & 10.5 & 5.0 & 4.9 & 6.8 & 7.3 & 7.2 & 4.8 \\
\hline Duration in current company & 0.0 & 48.5 & 6.2 & 6.2 & 6.0 & 6.2 & 3.3 & 3.3 \\
\hline $\begin{array}{l}\text { Cumulative duration in } \\
\text { unemployed }\end{array}$ & 0.0 & 22.3 & 1.2 & 1.2 & 0.7 & 0.5 & 0.5 & 0.7 \\
\hline Married or in partnership (\%) & 0 & 1 & 73.0 & 73.4 & 67.0 & 69.3 & 40.5 & 41.6 \\
\hline No children (\%) & 0 & 2 & & & & & & \\
\hline Children younger than $6(\%)$ & & & 13.1 & 13.0 & 12.1 & 13.9 & 10.7 & 14.6 \\
\hline Children aged 7-18 (\%) & & & 24.3 & 24.3 & 22.6 & 24.6 & 13.7 & 16.0 \\
\hline Homeowner (\%) & 0 & 1 & 45.0 & 44.8 & 46.4 & 51.0 & 32.7 & 25.4 \\
\hline \multicolumn{9}{|l|}{ Regional characteristics } \\
\hline Unemployment rate & 0.9 & 36.3 & 16.4 & 16.5 & 15.7 & 15.5 & 16.5 & 16.7 \\
\hline Distance in km & 15.9 & 281.0 & 120.3 & 121.1 & 116.2 & 107.4 & 118.2 & 125.2 \\
\hline Number of cases & 73,631 & & & 68,685 & 810 & 4,457 & 168 & 657 \\
\hline
\end{tabular}

Note: * In the year before commuting or migration. SOEP 1992-2013.

We control for the time spent since the first commuting episode, tenure at the current company, and cumulative duration of unemployment in years, employment status, monthly gross labor income, homeownership, distance between own region and the next western German region (NUTS 3 level), and regional unemployment rates. In addition we control for a range of individual characteristics that are known to be 
correlated with mobility, such as gender, being married or having a partner, and the interaction between those variables and age, children, and children's age.

\subsection{Methods}

In the first step we employ multilevel multinomial logit models with random effects (RE) that allow us to investigate mobility choices simultaneously, while accounting for the nested structure of the panel data. In the second step we use cross-classified RE logit models to investigate how migration and commuting decisions are interrelated, as people relocate also within eastern Germany, which violates the nested structure upon which standard hierarchical models are estimated (Rabe-Hesketh and Skrondal 2012: Chapter 9).

\section{Results}

\subsection{Who chooses to commute and who chooses to migrate from eastern to western Germany?}

With every year above nine years spent in education, the likelihood of commuting compared to the likelihood of remaining immobile is reduced by $5.4 \%$ (calculated: $\exp (-0.055)-1)$, while the likelihood of migrating increases by $7.7 \%$ (Table 2 Model I). Occupational-educational mismatches have, in turn, a negative effect on both forms of mobility even if the effect is not statistically significant for commuters (see Model I). We also find a significant interaction between education and distance for commuters, which suggests that education has a positive influence on commuting only in regions that are far away from western Germany, whereas in regions close to western Germany the higher educated are less likely to commute (Model II). We do not find a similar effect of education and distance for migrants or a statistically significant effect of occupational-educational mismatches. People who are employed in inadequately matched jobs do not differ in their likelihood of commuting or migrating over long distances from those who are working in jobs that are adequately matched. 
Table 2: $\quad$ Estimated regression coefficients and standard errors from multinomial two-level logit models predicting commuting (Com.) and migration (Mig.) from eastern to western Germany

\begin{tabular}{|c|c|c|c|c|c|c|}
\hline & \multicolumn{2}{|c|}{$\mathbf{I}$} & \multicolumn{2}{|c|}{ II } & \multicolumn{2}{|c|}{ III } \\
\hline & Com. & Mig. & Com. & Mig. & Com. & Mig. \\
\hline \multicolumn{7}{|l|}{ Individual characteristics } \\
\hline Education in years ${ }^{1}$ & $\begin{array}{c}-0.055^{*} \\
(0.023)\end{array}$ & $\begin{array}{c}0.075^{*} \\
(0.030)\end{array}$ & $\begin{array}{l}-0.214^{\star \star \star} \\
(0.052)\end{array}$ & $\begin{array}{c}0.056 \\
(0.069)\end{array}$ & $\begin{array}{c}-0.055^{*} \\
(0.023)\end{array}$ & $\begin{array}{c}0.075^{*} \\
(0.030)\end{array}$ \\
\hline Occupational-educational mismatch ${ }^{1}$ & $\begin{array}{c}-0.062 \\
(0.098)\end{array}$ & $\begin{array}{c}-0.361^{*} \\
(0.201)\end{array}$ & $\begin{array}{c}-0.065 \\
(0.098)\end{array}$ & $\begin{array}{c}-0.347^{*} \\
(0.200)\end{array}$ & $\begin{array}{c}-0.163 \\
(0.219)\end{array}$ & $\begin{array}{c}-0.208 \\
(0.497)\end{array}$ \\
\hline Log (monthly gross income) & $\begin{array}{l}1.000^{* * *} \\
(0.073)\end{array}$ & $\begin{array}{l}0.757^{\star \star *} \\
(0.126)\end{array}$ & $\begin{array}{l}0.999^{* * *} \\
(0.073)\end{array}$ & $\begin{array}{l}0.760^{\star * \star} \\
(0.125)\end{array}$ & $\begin{array}{l}1.002^{\star \star \star} \\
(0.073)\end{array}$ & $\begin{array}{l}0.758^{\star \star \star} \\
(0.126)\end{array}$ \\
\hline \multicolumn{7}{|c|}{ Ref. group: Part-time, marginally employed, and in apprenticeship } \\
\hline Full-time employed & $\begin{array}{c}-0.166 \\
(0.111)\end{array}$ & $\begin{array}{r}-0.030 \\
(0.185)\end{array}$ & $\begin{array}{c}-0.169 \\
(0.111)\end{array}$ & $\begin{array}{c}-0.015 \\
(0.185)\end{array}$ & $\begin{array}{c}-0.170 \\
(0.111)\end{array}$ & $\begin{array}{c}-0.029 \\
(0.185)\end{array}$ \\
\hline Duration spent in current company & $\begin{array}{c}-0.063^{* * *} \\
(0.007)\end{array}$ & $\begin{array}{c}-0.040^{\star \star *} \\
(0.012)\end{array}$ & 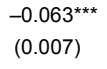 & $\begin{array}{l}-0.040^{\text {*** }} \\
(0.012)\end{array}$ & $\begin{array}{l}-0.063^{\star \star \star} \\
(0.007)\end{array}$ & $\begin{array}{l}-0.040^{\star \star \star} \\
(0.012)\end{array}$ \\
\hline Cumulative duration in unemployment & $\begin{array}{c}-0.040 \\
(0.034)\end{array}$ & $\begin{array}{r}-0.082 \\
(0.062)\end{array}$ & $\begin{array}{c}-0.038 \\
(0.034)\end{array}$ & $\begin{array}{c}-0.083 \\
(0.062)\end{array}$ & $\begin{array}{c}-0.041 \\
(0.034)\end{array}$ & $\begin{array}{c}-0.082 \\
(0.062)\end{array}$ \\
\hline \multicolumn{7}{|l|}{ Ref. group: Older than $\mathbf{4 0}$} \\
\hline Aged 35-39 & $\begin{array}{c}0.086 \\
(0.106)\end{array}$ & $\begin{array}{l}0.595^{\star *} \\
(0.223)\end{array}$ & $\begin{array}{c}0.086 \\
(0.106)\end{array}$ & $\begin{array}{l}0.604^{* *} \\
(0.222)\end{array}$ & $\begin{array}{c}0.087 \\
(0.106)\end{array}$ & $\begin{array}{l}0.600^{\star *} \\
(0.223)\end{array}$ \\
\hline Aged 30-34 & $\begin{array}{c}0.027 \\
(0.123)\end{array}$ & $\begin{array}{l}0.704^{\star *} \\
(0.227)\end{array}$ & $\begin{array}{c}0.032 \\
(0.123)\end{array}$ & $\begin{array}{l}0.711^{* *} \\
(0.226)\end{array}$ & $\begin{array}{c}0.034 \\
(0.123)\end{array}$ & $\begin{array}{l}0.701^{\star *} \\
(0.227)\end{array}$ \\
\hline Aged 25-29 & $\begin{array}{r}-0.016 \\
(0.139)\end{array}$ & $\begin{array}{l}0.933^{* * *} \\
(0.227)\end{array}$ & $\begin{array}{c}-0.015 \\
(0.138)\end{array}$ & $\begin{array}{l}0.955^{* * *} \\
(0.226)\end{array}$ & $\begin{array}{c}-0.013 \\
(0.139)\end{array}$ & $\begin{array}{l}0.933^{\star * *} \\
(0.227)\end{array}$ \\
\hline Aged 20-24 & $\begin{array}{c}0.158 \\
(0.162)\end{array}$ & $\begin{array}{l}1.501^{\star \star \star} \\
(0.247)\end{array}$ & $\begin{array}{c}0.154 \\
(0.162)\end{array}$ & $\begin{array}{l}1.503^{* * *} \\
(0.246)\end{array}$ & $\begin{array}{c}0.163 \\
(0.162)\end{array}$ & $\begin{array}{l}1.491^{\star \star \star} \\
(0.247)\end{array}$ \\
\hline Younger than 19 & $\begin{array}{c}0.128 \\
(0.227)\end{array}$ & $\begin{array}{l}0.913^{* *} \\
(0.353)\end{array}$ & $\begin{array}{c}0.108 \\
(0.227)\end{array}$ & $\begin{array}{c}0.885^{*} \\
(0.352)\end{array}$ & $\begin{array}{c}0.129 \\
(0.227)\end{array}$ & $\begin{array}{c}0.907^{*} \\
(0.353)\end{array}$ \\
\hline Female & $\begin{array}{c}-0.270 \\
(0.179)\end{array}$ & $\begin{array}{l}0.818^{* * *} \\
(0.207)\end{array}$ & $\begin{array}{c}-0.599^{* *} \\
(0.230)\end{array}$ & $\begin{array}{l}1.088^{* * *} \\
(0.278)\end{array}$ & $\begin{array}{c}-0.321+ \\
(0.181)\end{array}$ & $\begin{array}{l}0.846^{\star \star \star} \\
(0.210)\end{array}$ \\
\hline Married or living in a partnership & $\begin{array}{c}-0.230+ \\
(0.131)\end{array}$ & $\begin{array}{l}-0.773^{\star \star *} \\
(0.215)\end{array}$ & $\begin{array}{c}-0.197 \\
(0.132)\end{array}$ & 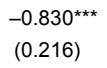 & $\begin{array}{c}-0.224+ \\
(0.131)\end{array}$ & $\begin{array}{c}-0.793^{\star \star \star} \\
(0.215)\end{array}$ \\
\hline Married or living in a partnership *female & $\begin{array}{c}-0.429^{*} \\
(0.187)\end{array}$ & $\begin{array}{c}-0.819^{\star *} \\
(0.266)\end{array}$ & $\begin{array}{c}-0.491^{\text {** }} \\
(0.189)\end{array}$ & $\begin{array}{c}-0.731^{* *} \\
(0.269)\end{array}$ & $\begin{array}{c}-0.448^{*} \\
(0.187)\end{array}$ & $\begin{array}{c}-0.788^{\star \star} \\
(0.266)\end{array}$ \\
\hline Ref. group: No children & & & & & & \\
\hline Children younger than 6 & $\begin{array}{c}0.089 \\
(0.106)\end{array}$ & $\begin{array}{c}0.006 \\
(0.200)\end{array}$ & $\begin{array}{c}0.089 \\
(0.105)\end{array}$ & $\begin{array}{c}0.003 \\
(0.199)\end{array}$ & $\begin{array}{c}0.086 \\
(0.106)\end{array}$ & $\begin{array}{c}0.004 \\
(0.200)\end{array}$ \\
\hline Children aged $7-18$ & $\begin{array}{c}-0.421^{\text {** }} \\
(0.089)\end{array}$ & $\begin{array}{r}-0.368^{*} \\
(0.184)\end{array}$ & $\begin{array}{c}-0.423^{\star \star *} \\
(0.089)\end{array}$ & $\begin{array}{c}-0.348+ \\
(0.184)\end{array}$ & $\begin{array}{c}-0.421^{\star \star \star} \\
(0.089)\end{array}$ & $\begin{array}{c}-0.362^{*} \\
(0.184)\end{array}$ \\
\hline Homeowner & $\begin{array}{l}0.305^{\star * *} \\
(0.088)\end{array}$ & $\begin{array}{l}-0.723^{\star \star *} \\
(0.144)\end{array}$ & $\begin{array}{l}0.299^{* * *} \\
(0.088)\end{array}$ & $\begin{array}{l}-0.722^{\star \star *} \\
(0.144)\end{array}$ & $\begin{array}{l}0.305^{\star \star \star} \\
(0.088)\end{array}$ & $\begin{array}{c}-0.728^{\star \star *} \\
(0.144)\end{array}$ \\
\hline Regional characteristics & & & & & & \\
\hline Unemployment rate & $\begin{array}{c}0.004 \\
(0.007)\end{array}$ & $\begin{array}{c}0.020 \\
(0.013)\end{array}$ & $\begin{array}{c}0.005 \\
(0.007)\end{array}$ & $\begin{array}{c}0.018 \\
(0.013)\end{array}$ & $\begin{array}{c}0.004 \\
(0.007)\end{array}$ & $\begin{array}{c}0.020 \\
(0.013)\end{array}$ \\
\hline Distance (in 100 km) & $\begin{array}{c}-0.541^{* * *} \\
(0.097)\end{array}$ & $\begin{array}{c}0.036 \\
(0.122)\end{array}$ & $\begin{array}{l}-0.881^{\text {***}} \\
(0.161)\end{array}$ & $\begin{array}{r}-0.143 \\
(0.204)\end{array}$ & $\begin{array}{c}-0.533^{\star \star \star} \\
(0.101)\end{array}$ & $\begin{array}{c}0.025 \\
(0.130)\end{array}$ \\
\hline
\end{tabular}


Melzer \& Hinz: The role of education and educational-occupational mismatches

Table 2: (Continued)

\begin{tabular}{|c|c|c|c|c|c|c|}
\hline & \multicolumn{2}{|c|}{ I } & \multicolumn{2}{|c|}{ II } & \multicolumn{2}{|c|}{ III } \\
\hline & Com. & Mig. & Com. & Mig. & Com. & Mig. \\
\hline \multicolumn{7}{|l|}{ Interaction terms } \\
\hline \multirow[t]{2}{*}{ Education*female } & & & $0.102^{*}$ & -0.076 & & \\
\hline & & & $(0.043)$ & $(0.053)$ & & \\
\hline \multirow[t]{2}{*}{ Education* distance (in $100 \mathrm{~km})^{1}$} & & & $0.099^{\star *}$ & 0.049 & & \\
\hline & & & $(0.036)$ & $(0.046)$ & & \\
\hline \multirow[t]{2}{*}{ Occupational-educational mismatch *female } & & & & & $0.382+$ & -0.481 \\
\hline & & & & & $(0.195)$ & $(0.391)$ \\
\hline Occupational-educational mismatch *distance (in & & & & & -0.049 & 0.011 \\
\hline $100 \mathrm{~km})^{1}$ & & & & & $(0.163)$ & $(0.336)$ \\
\hline \multirow[t]{2}{*}{ Variance of the random effect term } & $20.497^{\star * \star}$ & $9.443^{\star \star *}$ & $20.415^{\star \star \star}$ & $9.545^{\star \star *}$ & $20.524^{* \star \star}$ & $9.446^{* \star *}$ \\
\hline & $(1.367)$ & $(1.534)$ & $(1.366)$ & $(1.554)$ & $(1.370)$ & $(1.533)$ \\
\hline \multirow[t]{2}{*}{ Covariance of the RE terms } & $12.348^{\star \star \star}$ & & $12.523^{\star \star \star}$ & & $12.377^{\star \star \star}$ & \\
\hline & $(1.257)$ & & $(1.274)$ & & $(1.259)$ & \\
\hline Number of cases & 48,788 & & 48,788 & & 48,788 & \\
\hline Number of individuals & 7,399 & & 7,399 & & 7,399 & \\
\hline
\end{tabular}

Note: SOEP 1992-2013; Standard errors in parentheses; $+p<0.10,{ }^{*} p<0.05,{ }^{* \star} p<0.01,{ }^{* \star *} p<0.001 ;{ }^{1}$ one sided test.

As previous literature on migration from eastern to western Germany indicates gender-specific effects (e.g., Hunt 2006; Melzer 2013), Model II and III display genderspecific differences in education and educational-occupational mismatches using interactions. Although higher education reduced the likelihood of commuting for both men and women, the effect is half as strong for women. As in the joint Model I, there is a negative effect on commuting for men working in inadequately matched jobs (see Model II). For women working in inadequately matched jobs, the likelihood of commuting increases by $24.4 \%$ (calculated based on Model III: $\exp (-0.163+-$ $0.321+0.382)-1)$.

Both men and women in partnerships are less likely to migrate than single persons. However, the likelihood of commuting for men in partnerships is only $20.5 \%$ lower than for single men, while the likelihood of commuting for women in partnerships is $60.5 \%$ lower.

\subsection{Commuting as a stepping-stone, or as an alternative?}

Table 3 lists the results of the cross-classified logistic hierarchical models with RE predicting migration from eastern to western Germany. Most variables display similar effects to those estimated with the multinomial logit models in Table 2. 
Commuters are four times more likely to migrate than persons remaining immobile (Model I). However, with every additional year that passes since the first commuting episode, the likelihood of migrating is reduced by $25.1 \%$.

\section{Table 3: Estimated regression coefficients and standard errors from cross- classified multilevel logit models predicting migration from eastern to western Germany}

\begin{tabular}{|c|c|c|c|c|c|c|}
\hline & 1 & & II & & III & \\
\hline \multicolumn{7}{|l|}{ Individual characteristics } \\
\hline Commuter & $1.559^{* * *}$ & $(0.108)$ & $1.240^{\star \star *}$ & $(0.262)$ & $1.408^{\star \star \star}$ & $(0.154)$ \\
\hline Duration since first commuting & $-0.289^{* * *}$ & $(0.080)$ & $-0.287^{* * *}$ & $(0.080)$ & $-0.289^{\star \star \star}$ & $(0.080)$ \\
\hline Education in years & $0.110^{* * *}$ & $(0.018)$ & $0.132^{\star \star *}$ & $(0.028)$ & $0.109^{\star * *}$ & $(0.018)$ \\
\hline Occupational-educational mismatch & $-0.341^{*}$ & $(0.160)$ & $-0.330^{*}$ & $(0.160)$ & -0.078 & $(0.282)$ \\
\hline Log (monthly gross income) & 0.024 & $(0.030)$ & 0.021 & $(0.030)$ & 0.025 & $(0.030)$ \\
\hline Female & $0.548^{* * *}$ & $(0.112)$ & $0.579^{\star *}$ & $(0.177)$ & $0.501^{\text {***}}$ & $(0.123)$ \\
\hline \multicolumn{7}{|l|}{ Interaction terms } \\
\hline Commuter*female & & & $0.824^{*}$ & $(0.350)$ & 0.283 & $(0.201)$ \\
\hline Commuter*education & & & 0.041 & $(0.052)$ & & \\
\hline Education ${ }^{\star}$ female & & & -0.034 & $(0.036)$ & & \\
\hline Commuter*education ${ }^{\star}$ female & & & $-0.124+$ & $(0.072)$ & & \\
\hline $\begin{array}{l}\text { Commuter*occupational-educational } \\
\text { mismatch }\end{array}$ & & & & & -0.054 & $(0.521)$ \\
\hline Occupational-educational mismatch ${ }^{\star}$ female & & & & & 0.244 & $(0.673)$ \\
\hline $\begin{array}{l}\text { Commuter*occupational-educational } \\
\text { mismatch*female }\end{array}$ & & & & & -0.506 & $(0.382)$ \\
\hline Variance of the random effect term (regions) & $-1.132^{\star * *}$ & $(0.214)$ & $-1.118^{\star \star \star}$ & $(0.213)$ & $-1.124^{\star \star \star}$ & $(0.214)$ \\
\hline Variance of the random effect term (years) & $-1.096^{* * *}$ & $(0.181)$ & $-1.105^{\star * *}$ & $(0.182)$ & $-1.101^{\star \star *}$ & $(0.182)$ \\
\hline Number of cases & 73,631 & & 73,631 & & 73,631 & \\
\hline Number of individuals & 9,477 & & 9,477 & & 9,477 & \\
\hline Log likelihood test & -3.229 & & -3.224 & & -3.227 & \\
\hline
\end{tabular}

Note: SOEP 1992-2013; Standard errors in parentheses. Controlled for log monthly gross income; employment status; duration spent at company; duration spent unemployed; age; marital status; marital status`female; children, homeownership, regional unemployment rates. $+p<0.10,{ }^{\star} p<0.05,{ }^{* *} p<0.01,{ }^{* \star *} p<0.001$.

Model II investigates whether education influences the mobility of men and women differently, using a three-way interaction of the variables 'female,' 'commuter,' and 'education.' For all groups, men and women as well as commuters and stayers, the likelihood of migrating increases with higher education, but the likelihood of the lowand highly educated migrating varies significantly only for commuting men (see Figure 1). Commuters are more likely to migrate than stayers, independent of gender, but among commuters women are more likely to migrate than men. Finally, commuting 
women have a very high likelihood of migrating, regardless of their education, comparable only to the likelihood of migrating of commuting men with a high level of education. Stayers and commuters working in inadequately matched jobs are, independent of their gender, less likely to migrate (compare Model I and III).

Figure 1: Predicted margins for the probability of migration, dependent on education. The estimations are based on Model II Table 3

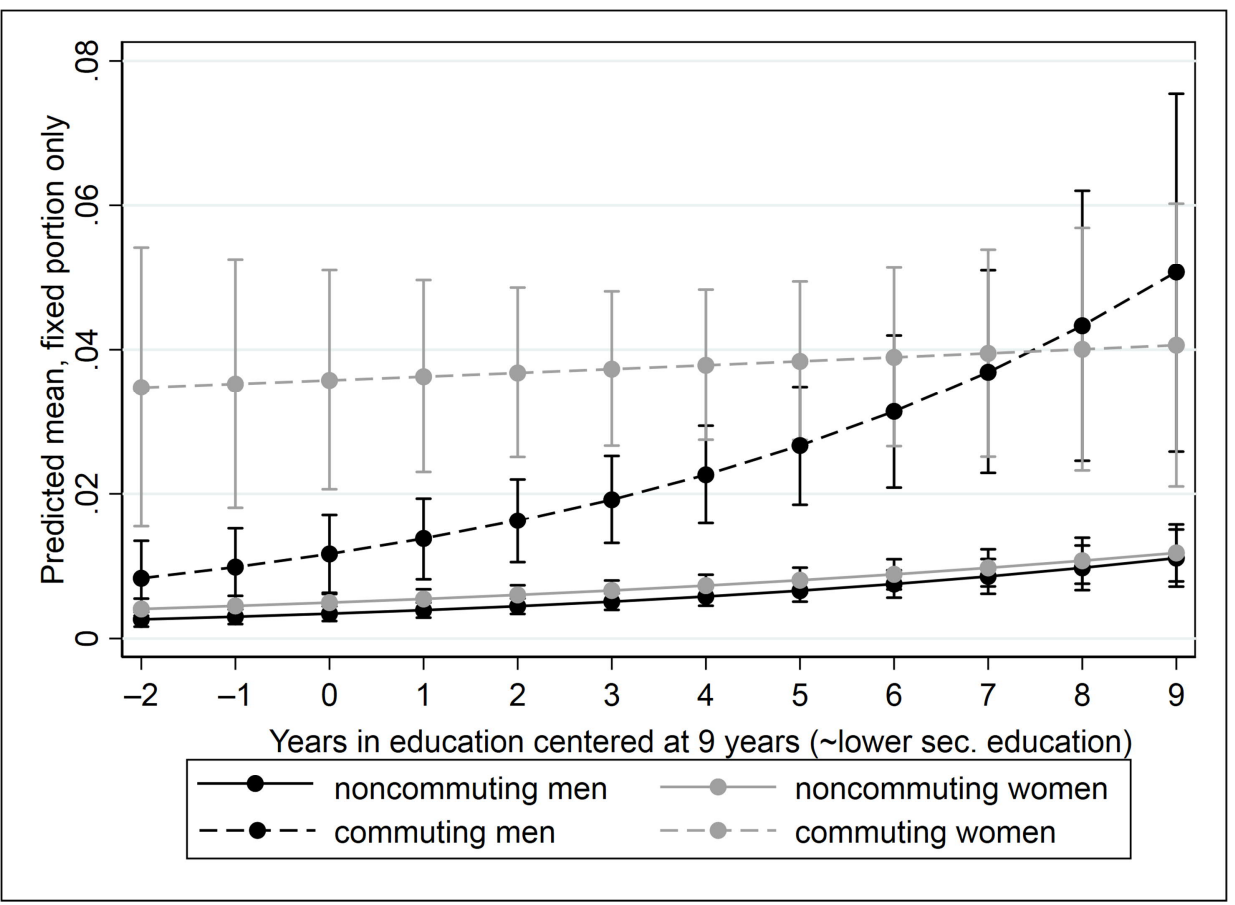

\section{Discussion and conclusion}

Based on multilevel multinomial regressions, we show that people with higher education are more likely to migrate than to remain immobile, while people who have spent less time in education prefer to commute (cf. Hunt 2006; Melzer 2013, 2016). While the existing literature is mixed it generally finds that migrants and commuters have higher education than those who remain immobile (e.g., Hunt 2006; Lundholm 2010; Melzer 2016; Nivalainen 2010; Romaní, Suriñach, and Artí́s 2003), and that 
commuters are usually less educated than migrants (e.g., Huber 2014). Some studies also indicate that commuters, especially those commuting for long periods, are more likely to have lower or middle levels of education (e.g., Sandow and Westin 2010). Therefore, our results highlight that studying migration and commuting separately leads to new insights.

Bad job matches reduce the likelihood of becoming mobile and the likelihood of migration even more than the likelihood of commuting. This finding corresponds to the assumptions expressed in the literature concerning educational-occupational matches, which describes working in a mismatched job as an alternative to regional mobility (Büchel and Battu 2003). Thus, it seems that people who have chosen to work in a mismatched job once, and have therefore already decided against regional mobility, are in general less prone to mobility and are more likely to remain immobile in later periods. However, there is a gender gap: our results indicate that while working in a mismatched job reduces the likelihood of commuting for men, it increases the likelihood for women.

Studying the sequence of mobility pattern by estimating cross-classified RE models, we found that commuting from eastern to western Germany has a strong positive effect on migration and is usually a stepping-stone to migration, rather than an alternative. Commuting provides the possibility of gathering necessary information on the future region or employer. However, the longer ago commuting started, the less likely commuters are to migrate. Thus, for one group of people, commuting functions as an alternative to migration. The crucial point is that there is a strong connection between commuting and migration. Investigating both mobility forms simultaneously broadens our understanding of people's choices, illustrating also that the highly educated are not necessarily prone to all forms of mobility, as they are more likely to migrate but less likely to commute from eastern to western Germany.

The research on regional migration emphasizes that women who have a partner are often not able to carry out their migration wishes, owing to conservative gender norms, and to their comparatively lower earnings and bargaining power within the couple, which affect mobility decisions (Nisic and Melzer 2016; Shauman and Noonan 2007). The fact that fewer women than men in partnerships commute seems to be just another 'symptom' of the inability of married women to pursue independent careers. However, women who start commuting are more likely than men to migrate soon afterwards. As women in partnerships are usually not able to outbalance their partners' mobility costs (cf. Nisic and Melzer 2016), the high likelihood of migration among commuting women indicates that they are a highly selected group.

In sum, this analysis of mobility from eastern to western Germany, covering more than 20 years after reunification, illustrates paradigmatically how the processes of commuting and selective migration influence the demographic structure of 
disadvantaged regions. Commuting to more attractive labor markets serves two distinct purposes. For the low educated it might be the only way to find an (adequate) job. Highly educated persons use commuting as a stepping-stone to migration. In addition, greater distances to western Germany even increase the likelihood that the highly educated will commute. Therefore, it is probable that only a thorough economic restructuring will prevent disadvantaged regions from experiencing a slow but steady outflow of human capital. As a byproduct, our analyses show a specific gender bias in commuting-induced migration, with women being more likely to migrate after commuting than men. In the long run, this will also skew the demography of eastern Germany. 


\section{References}

Borjas, G.J. (1987). Self-selection and the earnings of immigrants. The American Economic Review 77(4): 531-553.

Brown, D.L., Champion, T., Coombes, M., and Wymer, C. (2015). The migrationcommuting nexus in rural England: A longitudinal analysis. Journal of Rural Studies 41: 118-128. doi:10.1016/j.jrurstud.2015.06.005.

Büchel, F. and Battu, H. (2003). The theory of differential overqualification: Does it work? Scottish Journal of Political Economy 50(1): 1-16. doi:10.1111/14679485.00251 .

Eliasson, K., Lindgren, U., and Westerlund, O. (2003). Geographical labour mobility: Migration or commuting? Regional Studies 37(8): 827-837. doi:10.1080/ 0034340032000128749 .

Green, A.E., Hogarth, T., and Shackleton, R.E. (1999). Longer distance commuting as a substitute for migration in Britain: A review of trends, issues and implications. International Journal of Population Geography 5(1): 49-67. doi:10.1002/ (SICI)1099-1220(199901/02)5:1<49::AID-IJPG124>3.0.CO;2-O.

Haas, A. (2012). Mobilität zwischen Regionen: Pendlerströme fließen überwiegend von Ost nach West. Nürnberg: Institut für Arbeitsmarkt- und Berufsforschung (IABForum 2/2012). http://doku.iab.de/forum/2012/Forum2_2012_Haas.pdf.

Haas, A. and Hamann, S. (2008). Ost-West-Vergleich: Pendeln - ein zunehmender Trend, vor allem bei Hochqualifizierten. Nürnberg: Institut für Arbeitsmarktund Berufsforschung (IAB Kurzbericht 6/2008). http://doku.iab.de/kurzber/ 2008/kb0608.pdf.

Huber, P. (2012). Do commuters suffer from job-education mismatch? Applied Economics Letters 19(4): 349-352. doi:10.1080/13504851.2011.577004.

Huber, P. (2014). Are commuters in the EU better educated than non-commuters but worse than migrants? Urban Studies 51(3): 509-525. doi:10.1177/004209801 3498282 .

Huinink, J., Vidal, S., and Kley, S. (2014). Individuals' openness to migrate and job mobility. Social Science Research 44: 1-14. doi:10.1016/j.ssresearch.2013. 10.006 . 
Melzer \& Hinz: The role of education and educational-occupational mismatches

Hunt, J. (2006). Staunching emigration from East Germany: Age and the determinants of migration. Journal of the European Economic Association 4(5): 1014-1037. doi:10.1162/JEEA.2006.4.5.1014.

Kalter, F. (1994). Pendeln statt Migration? Die Wahl und Stabilität von WohnortArbeitsort-Kombinationen. Zeitschrift für Soziologie 23(6): 460-476. doi:10.1515/zfsoz-1994-0604.

Lundholm, E. (2010). Interregional migration propensity and labour market size in Sweden, 1970-2001. Regional Studies 44(4): 455-464. doi:10.1080/00343400 802662674 .

Melzer, S.M. (2013). Reconsidering the effect of education on East-West migration in Germany. European Sociological Review 29(2): 210-228. doi:10.1093/ esr/jcr056.

Melzer, S.M. (2016). Causes and consequences of the gender-specific migration from East to West Germany. Nürnberg: Institut für Arbeitsmarkt- und Berufsforschung.

Nisic, N. and Melzer, S.M. (2016). Explaining gender inequalities that follow couple migration. Journal of Marriage and Family 78(4): 1063-1082. doi:10.1111/ jomf.12323.

Nivalainen, S. (2010). Essays on family migration and geographical mobility in Finland. Helsinki: PTT Publications.

Pfaff, S. (2012). Commuting or relocation? Mobility decisions in Germany between 2000 and 2009. Zeitschrift für Soziologie 41(6): 458-477. doi:10.1515/zfsoz2012-0604.

Rabe-Hesketh, S. and Skrondal, A. (2012). Multilevel and longitudinal modeling using Stata. College Station: Stata Press.

Romaní, J., Suriñach, J., and Artí́s, M. (2003). Are commuting and residential mobility decisions simultaneous? The case of Catalonia, Spain. Regional Studies 37(8): 813-836. doi:10.1080/0034340032000128730.

Sandow, E. and Westin, K. (2010). The persevering commuter: Duration of longdistance commuting. Transportation Research Part A: Policy and Practice 44(6): 433-445. doi:10.1016/j.tra.2010.03.017.

Shauman, K.A. and Noonan, M.C. (2007). Family migration and labor force outcomes: Sex differences in occupational context. Social Forces 85(4): 1735-1764. doi:10.1353/sof.2007.0079. 
Sjaastad, L.A. (1962). The costs and returns of human migration. Journal of Political Economy 70(5): 80-93.

Statistisches Bundesamt (2010). 20 Jahre Deutsche Einheit: Wunsch oder Wirklichkeit. Wiesbaden: Statistisches Bundesamt.

Wagner, G.G., Frick, J.R., and Schupp, J. (2007). The German Socio-Economic Panel study (SOEP): Scope, evolution and enhancements. Schmollers Jahrbuch 127: 139-169. 
Melzer \& Hinz: The role of education and educational-occupational mismatches 